J. Amer. Soc. Hort. Sci. 117(4):547-550. 1992.

\title{
Maturity and Quality of 'Delicious' Apples as Influenced by Rootstock
}

\author{
John A. Barden and Michele E. Marini \\ Department of Horticulture, Virginia Polytechnic Institute and State University, Blacksburg, \\ VA 24061 \\ Additional index words. Malus domestica, soluble solids, ground color, firmness, starch, crop load
}

\begin{abstract}
A rootstock planting was established with 'Starkspur Supreme Delicious' apple (Malus dornestica Borkh.) on nine rootstock near Blacksburg, Va. Five uniformly sized fruit per tree were sampled 1 week before normal harvest and three five-fruit samples were taken at harvest. Rootstock had no consistent effect on the proportion of red surface, which averaged $\approx 90 \%$. Ground color was most yellow for fruit from trees on M.26 EMLA and least yellow from trees on M.27 EMLA, OAR1, and MAC24. Starch was lowest for fruit from trees on MAC9 and (Ottawa) 0.3 and highest from trees on OAR1 and MAC24. Firmness differences were neither large nor consistent and ranged from 71 to $78 \mathrm{~N}$. Soluble solids concentrations (SSC) of fruit were consistently high for fruit from trees on MAC9 and 0.3. A maturity index was calculated from the two harvest samples per year. Data for SSC, starch ratings, and ground color were ranked, and the highest maturity index was for fruit from trees on 0.3, MAC9, and M.26 EMLA.
\end{abstract}

The use of clonal, size-controlling rootstock is one of the most effective ways to regulate tree size in modern apple orchards. Since all of the currently available rootstock have weaknesses, a nationwide and international effort is underway to evaluate apple rootstock material; the title is Regional Project NC-140. Among the factors being evaluated are tree size, precocity, yield, anchorage, suckering, arid susceptibility to various biotic and abiotic factors.

Researchers have reported an influence of rootstock on specific indices of maturity. Hewetson (1944) reported that 'McIntosh' fruit matured $\approx 1$ week earlier when grown on an interstem of M.9 compared to several other interstems. Lord et al. (1985) found no consistent rootstock effect on flesh firmness of 'Empire'. SSCs were slightly higher in fruit from trees on M.27 than from trees on M.26 or several interstem combinations. In 1 of 2 years starch levels declined sooner in fruit from trees on M.27 and M.9 than from trees on M.26; in the other year, there were no differences. Senescent breakdown was more severe with fruit from trees on M.26 than in fruit from either M.9 or M.27. Perry and Dilley (1984) reported that there were no differences in flesh firmness, postharvest softening, or starch disappearance of 'Empire' fruit from trees on MM.111 with and without M.9 interstems. Fruit from interstem trees tended to have higher rates of ethylene production, but differences were not consistent. The objective of our study was to assess the effect of several rootstock on the maturity, quality, and storage life of 'Starkspur Supreme Delicious' apples.

\section{Materials and Methods}

'Starkspur Supreme Delicious' trees on nine rootstock were planted at the Horticulture Research Farm near Blacksburg, Va. The experiment was a randomized complete-block design with nine rootstock treatments and 10 single-tree replications. Replications 1-5 were planted on 21 Apr. 1980; 6-10 were planted on 8 Apr. 1981. Rootstock were M.27 EMLA, M.9, M.9 EMLA, MARK (MAC9), Ottawa (0.3), M.26 EMLA, Oregon Apple Rootstock (OAR) 1, M.7 EMLA, and Michigan Apple Clone

Received for publication 22 Aug. 1991. Accepted for publication 4 Mar. 1992 We gratefully acknowledge partial financial support from the Rootstock Research Foundation of the International Dwarf Fruit Tree Assn. The cost of publishing this paper was defrayed in part by the payment of page charges. Under postal regulations, this paper therefore must be hereby marked advertisement solely to indicate this fact.
(MAC) 24. Tree spacing was $3.5 \times 5.5 \mathrm{~m}$. Two rows of alternating trees of 'McIntosh'/M.26 and 'Golden Delicious'/M.26 were included as pollinizers. Trees in replications 1-5 were not supported; those in 6-10 were supported by a post and a single tie at $1 \mathrm{~m}$. Additional details are in the 5-year report (NC-140, 1987) and the final report (NC-140, 1991).

The soil was a well-drained silt loam; $\mathrm{pH}$ 6.7. All trees were fertilized annually with urea that was spread by hand under the dripline; routine weed and pest control practices were followed. In years and on trees where fruit set was excessive, clusters with multiple fruit were thinned by hand to single fruit.

Fruit were sampled in 1985, 1986, and 1987. The 1985 sample was taken only from replications 1-5 (planted in 1980); 1986 and 1987 samples were taken from all 10 replications. One fivefruit sample per tree was taken 1 week before normal harvest. At normal commercial harvest, three five-fruit samples per tree were taken. All fruits for a given sample date were within a $0.6-\mathrm{cm}$-diameter range and were from the periphery of the tree. Among sample dates, average fruit diameter ranged from 7.0 to $8.9 \mathrm{~cm}$. One sample of five fruit from each harvest was tested within $24 \mathrm{~h}$. The two remaining samples of five fruit were kept in air storage at $0 \pm 2 \mathrm{C}$ for $\approx 3$ months. Upon removal from cold storage, one five-fruit sample was tested after 1 day at $21 \mathrm{C}$; the other was tested after 7 days at $21 \mathrm{C}$.

Each fruit was rated for the percentage of the surface that was red, ground color (scale of $1=$ green to $4=$ yellow), flesh firmness (Effegi penetrometer with an 11-mm tip) on two peeled sides, starch rating (I-KI test), and incidence of disorders (bitter pit, cork spot, scald, internal breakdown, and water core). The juice extracted with the two pressure tests per fruit was combined for each five-fruit sample, and SSC was determined with an Atago hand refractometer (McCormick Fruit Tech, Yakima, Wash.).

Data on individual factors were subjected to analyses of variance and means were separated by Duncan's multiple range test. SSC and ground color data were ranked from low to high and starch rating data were ranked from high to low among rootstock within each replication for each of the two harvest samples for all 3 years (SAS Rank Procedure, SAS Institute, Cary, N.C.). The three ranks were averaged within each replication and sample and represent an overall maturity index.

Abbreviation: SSC, soluble solids concentration. 
Maturity indices were analyzed and found to be normally distributed (Proc Univariate, SAS Institute). The maturity index was then subjected to an analysis of variance and Duncan's multiple range test. (Data were also subjected to nonparametric analyses and conclusions were identical to those with the analysis of variance.)

\section{Results}

About $90 \%$ of the surface was red for both harvests in all 3 years. The differences due to rootstock were small and not consistent from year to year (data not shown).

Since there was not a significant rootstock $\times$ year interaction, ground color data are presented as means for the three years (Table 1). Fruit from trees on M.26 EMLA had the most yellow ground color followed by MAC9, M.9, M.9 EMLA, M.7 EMLA, and 0.3. Fruit from trees on M.27 EMLA had the least yellow ground color, but it was similar to that on fruit from OAR1 and MAC24.

Since there was not a significant rootstock $\times$ year interaction, starch rating data are presented as means for the three years (Table 1). Lowest starch levels were for fruit from trees on MAC9 and 0.3, but did not differ from those on several other rootstock. Starch levels were highest for fruit from trees on OAR1 and MAC24. Others were intermediate.

There was a significant $(P<0.01)$ rootstock $\times$ year interaction for flesh firmness (Table 2). In 1985, fruit were softest from trees on 0.3 followed closely by fruit from trees on M.9, M.9 EMLA, M.26 EMLA, MAC24, and M.7 EMLA. Fruit from trees on OAR1 and M.27 EMLA were the most firm. In 1986, fruit were least firm from trees on M.26 EMLA and most firm from trees on MAC9 and 0.3, with those from M.27 EMLA being of similar firmness. In 1987, the softest fruit were from trees on M.9 and MAC9 and most firm from trees on OAR1, MAC24, and M.7 EMLA, but fruit from others did not differ significantly from some in either group.

There was a significant $(P<0.01)$ interaction between year and rootstock for SCC (Table 3). In spite of the interaction, fruit from trees on 0.3 and MAC9 had consistently high SSC. Compared to fruit from trees on 0.3 and MAC9 in 1985, fruit from trees on M.26 EMLA, OAR1, M.7 EMLA, and MAC24 were significantly lower in SSC. In 1986 fruit from trees on

Table 1. Ground color and starch levels of 'Starkspur Supreme Delicious' apples as influenced by rootstock."

\begin{tabular}{lcc}
\hline \hline Rootstock & $\begin{array}{c}\text { Groundy } \\
\text { color }\end{array}$ & $\begin{array}{c}\text { Starch } \\
\text { level }\end{array}$ \\
\hline M.27 EMLA & $2.8 \mathrm{~d}^{\mathrm{w}}$ & $59 \mathrm{~b}$ \\
M.9 & $3.0 \mathrm{bc}$ & $56 \mathrm{bc}$ \\
M.9 EMLA & $3.0 \mathrm{bc}$ & $56 \mathrm{bc}$ \\
& & \\
& &
\end{tabular}

${ }^{2}$ Data are means across two harvest samples and one storage sample in 1985, 1986, and 1987 because rootstock $\times$ year interactions were nonsignificant.

'Ground color rated from 1 = green to $4=$ yellow.

${ }^{x}$ Fruit were sliced equatorially, dipped in an I-KI solution, and rated for the percentage of the fruit surface stained.

"Mean separation within columns by Duncan's multiple range test $(P$ $<0.05)$.
Table 2. Flesh firmness of 'Starkspur Supreme Delicious' apples as influenced by rootstock.

\begin{tabular}{lccc}
\hline \hline & \multicolumn{3}{c}{ Mean flesh firmness (N) } \\
\cline { 2 - 4 } Rootstock & 1985 & 1986 & 1987 \\
\hline M.27 EMLA & $75.2 \mathrm{a}^{\mathrm{y}}$ & $76.1 \mathrm{ab}$ & $74.3 \mathrm{bcd}$ \\
M.9 & $71.6 \mathrm{bc}$ & $74.7 \mathrm{~b}$ & $72.5 \mathrm{~d}$ \\
M.9 EMLA & $71.6 \mathrm{bc}$ & $74.7 \mathrm{~b}$ & $72.9 \mathrm{~cd}$ \\
MAC9 & $73.8 \mathrm{ab}$ & $78.3 \mathrm{a}$ & $72.1 \mathrm{~d}$ \\
M.26 EMLA & $71.6 \mathrm{bc}$ & $72.1 \mathrm{c}$ & $73.4 \mathrm{~cd}$ \\
M.7 EMLA & $72.5 \mathrm{bc}$ & $75.6 \mathrm{~b}$ & $75.2 \mathrm{abc}$ \\
O.3 & $71.2 \mathrm{c}$ & $77.8 \mathrm{a}$ & $73.4 \mathrm{~cd}$ \\
OAR1 & $75.6 \mathrm{a}$ & $75.2 \mathrm{~b}$ & $77.4 \mathrm{a}$ \\
MAC24 & $72.1 \mathrm{bc}$ & $74.7 \mathrm{~b}$ & $76.1 \mathrm{ab}$ \\
\hline
\end{tabular}

${ }^{\mathrm{z}}$ Year $\times$ rootstock interaction was significant $(P<0.01)$. Data are means for two harvests and one storage sample in each year.

${ }^{y}$ Mean separation within columns by Duncan's multiple range test $(P$ $<0.05)$.

Table 3. SSC of 'Starkspur Supreme Delicious' apples as influenced by rootstock.

\begin{tabular}{llll}
\hline \hline & \multicolumn{3}{c}{ SSC } \\
\cline { 2 - 4 } Rootstock & \multicolumn{1}{c}{1985} & 1986 & 1987 \\
\hline M.27 ELMA & $12.4 \mathrm{a}^{\mathrm{y}}$ & $13.8 \mathrm{ab}^{\mathbf{x}}$ & $15.1 \mathrm{~b}^{\mathbf{y}}$ \\
M.9 & $12.6 \mathrm{ab}$ & $13.9 \mathrm{ab}$ & $15.2 \mathrm{~b}$ \\
M.9 ELMA & $12.7 \mathrm{ab}$ & $14.3 \mathrm{a}$ & $15.3 \mathrm{~b}$ \\
MAC9 & $13.1 \mathrm{a}$ & $14.5 \mathrm{a}$ & $16.2 \mathrm{a}$ \\
M.26 ELMA & $12.8 \mathrm{~b}$ & $13.9 \mathrm{ab}$ & $15.7 \mathrm{~b}$ \\
M.7 ELMA & $12.3 \mathrm{c}$ & $14.1 \mathrm{ab}$ & $15.5 \mathrm{~b}$ \\
O.3 & $13.2 \mathrm{a}$ & $14.4 \mathrm{a}$ & $16.5 \mathrm{a}$ \\
OAR1 & $12.8 \mathrm{~cd}$ & $13.9 \mathrm{ab}$ & $15.4 \mathrm{c}$ \\
MAC24 & $12.3 \mathrm{~d}$ & $13.5 \mathrm{~b}$ & $15.7 \mathrm{~b}$ \\
\hline
\end{tabular}

${ }^{\mathrm{z}}$ Year $\times$ rootstock interaction was significant $(P<0.01)$. Data are means over harvest and one storage sample in each year.

${ }^{\mathrm{r}}$ Mean separation within column using adjusted least squares means due to significant covariate crop density.

${ }^{x}$ Mean separation within 1986 column by Duncan's multiple range test $(P<0.05)$.

MAC24 were among those lowest in SSC, but in 1987, all other rootstock resulted in fruit that were lower in SSC than those from MAC9 or O.3.

Levels of cork spot, bitter pit, scald, internal breakdown, and water core were low, and there were no significant differences among rootstock in any of the three years (data not shown).

The maturity indices showed a significant $(P<0.01)$ rootstock $\times$ year interaction (Table 4). In 1985, there were two groups with fruit from trees on M.7 EMLA, OAR1, and MAC24 having lower maturity indices than fruit from trees on the other six rootstock. In 1986, fruit from trees on O.3 had the highest maturity index, whereas fruit from trees on M.9 EMLA, MAC9, M.26 EMLA, and M.9 had somewhat lower maturity indices. Fruit from trees on OAR1, MAC24, and M.27 EMLA had similarly low maturity indices. In 1987, fruit from trees on 0.3 and MAC9 had high maturity indices; fruit from trees on M.26 EMLA and M.9 EMLA had nonsignificantly lower maturity indices; and OAR1, M.27 EMLA, and MAC24 were among the lowest. Over the three years of the study, O.3 resulted in consistently high maturity indices, followed by MAC9, M26 EMLA, M.9 EMLA, and M.9. The latest-maturing fruit were from trees on OAR1, MAC24, and M.7 EMLA. Fruit from trees on M.27 EMLA showed the greatest year-to-year variation.

Crop density varied due to rootstock and was generally high- 
Table 4. Maturity index ${ }^{z}$ of 'Starkspur Supreme Delicious' apples as influenced by rootstock in the $1980-81$ NC-140 trial.

\begin{tabular}{llcl}
\hline \hline & \multicolumn{3}{c}{ Maturity index } \\
\cline { 2 - 4 } Rootstock & 1985 & 1986 & 1987 \\
\hline M.27 EMLA & $6.3 \mathrm{a}^{\mathrm{x}}$ & $3.4 \mathrm{~cd}$ & $3.8 \mathrm{c}$ \\
M.9 & $5.5 \mathrm{a}$ & $5.2 \mathrm{~b}$ & $4.5 \mathrm{bc}$ \\
M.9 EMLA & $6.2 \mathrm{a}$ & $5.9 \mathrm{ab}$ & $4.9 \mathrm{abc}$ \\
MAC9 & $6.6 \mathrm{a}$ & $5.5 \mathrm{~b}$ & $6.1 \mathrm{a}$ \\
M.26 EMLA & $6.2 \mathrm{a}$ & $5.5 \mathrm{~b}$ & $5.6 \mathrm{ab}$ \\
M.7 EMLA & $3.2 \mathrm{~b}$ & $4.7 \mathrm{bc}$ & $4.4 \mathrm{bc}$ \\
O.3 & $5.6 \mathrm{a}$ & $7.0 \mathrm{a}$ & $6.4 \mathrm{a}$ \\
OAR1 & $3.2 \mathrm{~b}$ & $2.8 \mathrm{~d}$ & $3.4 \mathrm{c}$ \\
MAC24 & $2.3 \mathrm{~b}$ & $3.4 \mathrm{~cd}$ & $4.0 \mathrm{c}$ \\
\hline
\end{tabular}

"Maturity index based on SSC, starch, and ground color data collected at two harvests per year (preharvest and harvest). Higher indices indicate more advanced maturity. SSC and ground color data were ranked from 1 to 10 from low to high; starch data were ranked from high to low.

yata for 1985 are for replications 1-5; for 1986 and 1987 for replications $1-10$.

xMean separation within columns by Duncan's multiple range test $(P$ $<0.05)$.

Table 5. Crop density of 'Starkspur Supreme Delicious' apples as influenced by rootstock in the 1980-81 NC-140 trial.

\begin{tabular}{llcl}
\hline \hline & \multicolumn{3}{c}{ Crop density $^{\mathrm{y}}$} \\
\cline { 2 - 4 } Rootstock & 1985 & 1986 & 1987 \\
\hline M.27 EMLA & $4.7 \mathrm{ab}^{\mathrm{x}}$ & $3.8 \mathrm{a}$ & $3.5 \mathrm{a}$ \\
M.9 & $5.2 \mathrm{a}$ & $4.1 \mathrm{a}$ & $2.9 \mathrm{a}$ \\
M.9 EMLA & $5.1 \mathrm{a}$ & $3.5 \mathrm{a}$ & $2.8 \mathrm{a}$ \\
MAC9 & $5.5 \mathrm{a}$ & $2.9 \mathrm{a}$ & $3.4 \mathrm{a}$ \\
M.26 EMLA & $3.8 \mathrm{bc}$ & $3.1 \mathrm{a}$ & $1.9 \mathrm{~b}$ \\
M.7 EMLA & $2.8 \mathrm{~cd}$ & $1.0 \mathrm{~b}$ & $0.6 \mathrm{e}$ \\
O.3 & $5.7 \mathrm{a}$ & $3.2 \mathrm{a}$ & $2.1 \mathrm{~b}$ \\
OAR1 & $1.7 \mathrm{de}$ & $1.2 \mathrm{~b}$ & $0.8 \mathrm{c}$ \\
MAC24 & $1.4 \mathrm{e}$ & $0.4 \mathrm{~b}$ & $0.1 \mathrm{c}$ \\
\hline
\end{tabular}

2Data are means for five observations (reps) in 1985 and 10 observations (reps) in 1986 and 1987.

yCrop density expressed as number of fruit per square centimeter of trunk cross-sectional area.

×Mean separation within columns by Duncan's multiple range test $(P$ $<0.05$ ).

est for trees on M.27 EMLA, M.9, M.9 EMLA, MAC9, and 0.3 (Table 5). Trees on M.7 EMLA, OAR1, and MAC24 were consistently low in crop density. Had thinning by hand not been practiced each year, severe overcropping would have occurred with most of the more precocious rootstock. Cropping of trees on M.7 EMLA, OAR1, and MAC24 was not high enough to require any thinning from 1985 through 1987.

\section{Discussion}

There are several reports of rootstock effects on apple maturity, quality, and storage life. Zeiger and Tukey (1960) reviewed the history of the Mailing apple rootstock in America up to 1960 and cited reports of advanced maturity and increased color of fruit from trees on certain rootstock, particularly M.9. Comparison of results among studies is made difficult not only by differences in scion cultivars, but in many cases there were few rootstock in common. As noted by Autio (1991), there is often confounding due to variation in crop load, light level, and fruit size.

Given the above concerns, there are some useful and inter- esting comparisons to be made among the published results. In a 4-year study in Washington, Larsen et al. (1985) found that 'Wellspur Delicious' and 'Red King Delicious' fruit had higher SSC and tended to develop yellow ground color earlier when grown on M.26 than on M.7. Drake et al. (1988) reported that 'Goldspur Golden Delicious' fruit from trees on M.26 were more yellow and had higher SSC than those from trees on MM.111 or seedling rootstock. In general, our data on ground color (Table 1), SSC (Table 3), and maturity index (Table 4) agree with the results of Larsen et al. (1985) and Drake et al. (1988) in that M.26 induced relatively early maturity of fruit.

Fallahi et al. (1985a) found that 'Starkspur Golden Delicious' fruit from trees on OAR1 had higher SSC and more yellow ground color at harvest than those from trees on M.26 or M.7. In a related paper, Fallahi et al. (1985b) reported that fruit of 'Starkspur Golden Delicious' from trees on M.26 rootstock had higher internal ethylene concentrations than fruit from trees on OAR1. Compared to fruit from trees on M.26 in our study, fruit from trees on OAR1 had greener ground color, higher starch ratings, firmer flesh, lower SSC, and a consistently lower maturity index ranking (Table 4). Also, trees on OAR1 averaged only about one-third the crop load of trees on M.26 EMLA (Table 5). Explanations for the different results of our study and those of Fallahi et al. (1985a, 1985b) are not clear but may be related to differences in cultivar or climate.

Using trees in an NC-140 planting comparable to ours, Autio (1991) found that M.27 EMLA advanced fruit ripening but that M.7 EMLA delayed fruit ripening. The other rootstock were inconsistent or intermediate in their effects on fruit ripening. In our study, M.27 EMLA and M.7 EMLA were intermediate between the early and late groups. In the Kentucky NC-140 trial, Brown and Wolfe (1992) found that fruit from trees on M.27 EMLA, MAC9, and M.9 EMLA had higher SSC than those from trees on M.7 EMLA, OAR1, M.26 EMLA, and MAC24. Flesh firmness was highest for fruit from trees on OAR1 and lowest for 0.3. These three studies illustrate well the potential variation even when both scion cultivar and rootstock are the same.

Autio (1991) found a strong positive relationship between crop density and date of ripening, i.e., delayed ripening was associated with high crop densities. He found the relationship to be similar among rootstock but variable among years. Of particular interest was that the crop density effect was greatest in the year of a summer drought. Autio (1991) removed the crop density effect from his ripening and quality data by using it as a covariate. We tested crop density as a covariate in the analysis of ground color, starch, SSC, and firmness in each year. The only three of the 12 analyses in which crop density was significant $(P \leq 0.05)$ were SSC in 1985 and 1987 and ground color in 1986. We suggest that the explanation for the strong effect of crop density found by Autio (1991) and the small effect in our data relates to thinning. We regulated cropping by thinning by hand, whereas Autio did no thinning (W. Autio, personal communication). The absence of thinning in Autio's experiment likely allowed much heavier cropping and much greater variation in crop density among rootstock than in our experiment.

Using maturity indices for 3 years of this study, fruit from trees on M.7 EMLA, OAR1, and MAC24 were three of the latest maturing while these trees consistently had the lowest crop density. Thus, in spite of sizeable differences in crop density among rootstock (Table 5), maturity differences of the fruit among rootstock (Table 4) are due, to a large degree, to rootstock or at least a factor other than crop density. Our use of 
fruit within a narrow size range also helped to minimize effects of crop density differences on the maturity indices studied.

There is considerable evidence that rootstock can alter the maturity of fruit sufficiently to be of commercial use in scheduling harvest or perhaps in deciding on which fruit to put into long-term storage. There is, however, a need for further research to sort out the consistency of effects among years, cultivars, and climates.

\section{Literature Cited}

Autio, W.R. 1991. Rootstock affect ripening and other qualities of 'Delicious' apples. J. Amer. Soc. Hort. Sci. 116:378-382.

Brown, G.R. and D. Wolfe. 1992. Rootstock affects maturity of 'Starkspur Supreme Delicious' apples. HortScience 27:76.

Drake, S.R., F.E. Larsen, J.K. Fellman, and S.S. Higgins. 1988. Maturity, storage quality, carbohydrate, and mineral content of 'Goldspur' apples as influenced by rootstock. J. Amer. Soc. Hort. Sci. 113:949-952.

Fallahi, E., D.G. Richardson, and M.N. Westwood. 1985a. Quality of apple fruit from a high density orchard as influenced by rootstock, fertilizers, maturity, and storage. J. Amer. Soc. Hort. Sci. 110:71-74
Fallahi, E., D.G. Richardson, and M.N. Westwood. 1985b. Influence of rootstock and fertilizers on ethylene in apple fruit during maturation and storage. J. Amer. Soc. Hort. Sci. 110:149-153.

Hewetson, F.N. 1944. Growth and yield of McIntosh apple trees as influenced by the use of various intermediate stem pieces. Proc. Amer. Soc. Hort. Sci. 45:181-186.

Larsen, F.E., R. Fritts, Jr., and K.L. Olsen. 1985. Rootstock influence on 'Delicious' and 'Golden Delicious' apple fruit quality at harvest and after storage. Scientia Hort. 26:339-349.

Lord, W.J., D.W. Greene, R.A. Damon, Jr., and J.H. Baker. 1985. Effects of stempiece and rootstock combinations on growth, leaf mineral concentrations, yield, and fruit quality of 'Empire' apple trees. J. Amer. Soc. Hort. Sci. 110:422-425.

NC-140. 1987. Growth and production of 'Starkspur Supreme Delicious' on 9 rootstock in the NC-140 cooperative planting. Fruit Var. J. 41:31-39.

NC-140. 1991. Performance of 'Starkspur Supreme Delicious' apple on 9 rootstock over 10 years in the NC-140 cooperative planting. Fruit Var. J. 45:192-199.

Perry, R.L. and D.R. Dilley. 1984. The influence of interstem on ripening indices of 'Empire' apples. Compact Fruit Tree 17:50-54.

Zeiger, D. and H.B. Tukey. 1960. An historical review of the Mailing apple rootstock in America. Michigan Agr. Expt. Sta. Circ. Bul. 226. 